Volume 4 | Issue 3

9-16-2017

\title{
Recognizing Challenges and Opportunities in the Quest to End Hunger
}

Jennifer Williams Zwagerman

Follow this and additional works at: https://scholarship.law.tamu.edu/lawreview

Part of the Agricultural Education Commons, Agricultural Science Commons, Agriculture Law Commons, Biotechnology Commons, Food and Drug Law Commons, Food Biotechnology Commons, Food Processing Commons, Genetics Commons, Human Rights Law Commons, Law and Society Commons, Molecular, Genetic, and Biochemical Nutrition Commons, Natural Law Commons, Natural Resources Law Commons, Other Food Science Commons, Other Genetics and Genomics Commons, Other Law Commons, Other Life Sciences Commons, Other Plant Sciences Commons, Plant Biology Commons, Property Law and Real Estate Commons, Science and Technology Law Commons, Social Welfare Law Commons, and the State and Local Government Law Commons

\section{Recommended Citation}

Jennifer W. Zwagerman, Recognizing Challenges and Opportunities in the Quest to End Hunger, 4 Tex. A\&M L. Rev. 315 (2017).

Available at: https://doi.org/10.37419/LR.V4.I3.1

This Article is brought to you for free and open access by Texas A\&M Law Scholarship. It has been accepted for inclusion in Texas A\&M Law Review by an authorized editor of Texas A\&M Law Scholarship. For more information, please contact aretteen@law.tamu.edu. 


\title{
SYMPOSIUM: AGRICULTURE, INTELLECTUAL PROPERTY, AND FEEDING THE WORLD IN THE 21ST CENTURY
}

\section{RECOGNIZING CHALLENGES AND OPPORTUNITIES IN THE QUEST TO END HUNGER*}

\author{
by Jennifer Williams Zwagerman+
}

\section{TABle of Contents}

I. Focusing the Discussion-What it Means to Feed THE World ................................. 316

II. Consumer Engagement-Friend or Foe? ........ 318

A. Food Policy Goes Mainstream ................. 318

B. Parallel or Intersecting Forces - Consumer Demand and Innovation................................ 319

III. Express Yourself-Communication Challenges .. 327

A. GMOs_Communication Case Study............ 327

B. Same Story, Different Technology?............. 329

C. Building Relationships and Understanding Needs ... 332

IV. Collaborate and Listen-Building

Relationships .............................. 333

V. Industry CONSOLIDATION-INNOVATION NECESSITY OR InNOVATION KILLER? .......................... 335

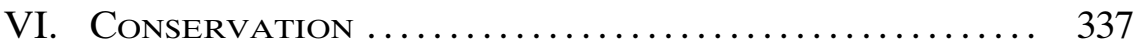

VII. Thinking Outside the Box, Creativity is Key to Feeding the World ............................ 339

VIII. Conclusion .................................... 341

As an attorney and professor that does not focus on intellectual property law, I was a bit apprehensive about providing a keynote address for a Symposium focusing on "Agriculture, Intellectual Property, and Feeding the World in the 21st Century." As I thought about this topic, knowing that there were other speakers who would focus more on the IP issues and technical aspects of various topics, I kept coming back to the importance of technology as we work

* Adapted from remarks of the Morning Keynote Address at the 2016 Texas A\&M Law Review Fall Symposium. Thank you to the Texas A\&M University School of Law and the Law Review staff for the opportunity to be a part of the Symposium, your hospitality, and your hard work in putting together a thoughtful and engaging discussion on this topic.

+ Jennifer Williams Zwagerman is the Associate Director of the Agricultural Law Center at Drake University Law School and also serves as Director of Career Development.

DOI: https://doi.org/10.37419/LR.V4.I3.1 
towards the goal of feeding the world, and the many ways in which innovation plays a role in meeting that goal. It also brought to mind some of the broader issues involving technology that can both impede and support attempts to successfully feed the world, both now and looking to the future.

Food. Agriculture. Technology. There is no doubt that when it comes to these areas of law, regulation, policy, and practice, there is much that binds them, and yet they are also very divisive. A quick scan of almost any major and reputable news source will provide articles on a daily basis that pertain to not just one, but often all three of these topics. They are independent industries-science, agricultural production, and food manufacturing, but the truth is that in today's world, they intersect more than ever. Consumer understanding of each of these industries is far from complete, and that can lead to many issues when it comes to the adoption of technology, agricultural production, and consumer food choices. When you incorporate government regulation, international relations, and infrastructure challenges, it becomes clear that technology alone will not feed the world. Feeding the world requires looking at issues beyond production and manufacturing, and into the challenges and issues that limit access to food and inputs.

When it comes to feeding the world, I believe that technology and innovation will be a key driver and a major part of any successful attempts at addressing this challenge. Technology does not just mean increased use of genetically engineered crops, although that may likely be a part of the solution. To successfully feed the growing world, we need to take a broader look at technology and how it can be used to address challenges that impact the ability to increase or sustain production. We also need to look at the barriers to the adoption of various forms of technology, and what needs to be done on a global scale to support sustainable and self-sufficient food production across the world. Strong communication across sectors and working collaboratively will be required to tackle broader issues surrounding food access and in protecting the interests of everyone involved from supplier to grower to consumer.

I hope to use this opportunity to provide a more holistic overview of the issues involving agriculture and technology that can both impede and support attempts to successfully feed the world. We cannot simply rely on technology to reach our goal of feeding the world. Instead, we have to focus on its interactions with the myriad other influences in food and agriculture, and I highlight several here.

\section{Focusing the Discussion - What it Means TO FeEd THE World}

In 2015, the United Nations (UN) estimated a world population of 7.3 billion people, expected to reach 8.5 billion by 2030 and by 2050 
the UN estimates the world population will be 9.7 billion people. ${ }^{1}$ The World Bank estimates that we need to increase our food production by $50 \%$ to meet the needs of the population in $2050 .^{2}$ Increasing our current agricultural production is not as simple as planting twice as many acres. Instead, there are a combination of challenges that need to be addressed in order to successfully increase food production, and ensure that the food is provided to those who need it. Loss of farm land, climate change, and depletion of natural resources across the world are challenges, ${ }^{3}$ as are the locations of centers of population growth and increasing food needs in countries that already face food insecurity challenges. ${ }^{4}$ The UN estimates that increases in population in African countries will "account for more than half of the world's population growth between 2015 and 2050."5 These countries that will see a population boom already have some of the highest level of hunger in the world: 20 of the African countries included in a 2014 UN Food \& Agriculture Organization report indicate that $15 \%$ or more of their populations suffer from hunger. ${ }^{6}$ China and India, the world's two largest countries, have current hunger levels of approximately $10 \%$ and $15 \%$ respectively. The areas in which we are expected to see large population increases are also areas in which we already struggle to feed the world. ${ }^{7}$

Food access and food security is not just an issue in the developing world. I live in the most populated county in Iowa, which recently started a campaign aimed at ending hunger locally. ${ }^{8}$ An estimated 55,000 people are food insecure in Polk County, over $10 \%$ of the population, including 1 out of 5 children. ${ }^{9}$ Even in a state that consistently is ranked in the top 5 states for overall agricultural production, hunger remains an issue. ${ }^{10}$ While it is estimated that the world produces

1. U.N. Dep't of Econ. \& Soc. Affairs, World Population Projected to Reach 9.7 Billion by 2050 (July 29, 2015), http://www.un.org/en/development/desa/news/popula tion/2015-report.html [https://perma.cc/99CU-5E3T].

2. Food Security, World Bank, http://www.worldbank.org/en/topic/foodsecurity [https://perma.cc/MEQ9-PAE8].

3. Id.; Farmland, AM. FARMLAND TR., https://www.farmland.org/our-work/areasof-focus/farmland [https://perma.cc/P599-5AF7]; Fred Magdoff, Global Resource Depletion: Is Population the Problem?, 64 Monthly Rev., Jan. 2013, at 13, 14-19.

4. U.N. Dep't of Econ. \& Soc. Affairs, supra note 1. See Food \& Agric. Org. of the U.N., The FAO Hunger Map 2015, http://www.fao.org/hunger/en/ [https://perma .cc/2A8B-CRJ6].

5. U.N. Dep't of Econ. \& Soc. Affairs, supra note 1.

6. Food \& Agric. Org. of the U.N., supra note 4.

7. U.N. Dep't of Econ. \& Soc. Affairs, supra note 1. See Food \& Agric. Org. of the U.N., supra note 4.

8. See Hunger Free Polk County, https://www.hungerfreepolkcounty.org/ [https://perma.cc/AD59-R9R7].

9. Id.; see Quick Facts: Polk County, Iowa, U.S. Census Bureau, https://www .census.gov/quickfacts/table/BZA210214/19153 [https://perma.cc/5LM7-2KJL].

10. FAQs, U.S. DeP'T Agric. Econ. Res. Serv., https://www.ers.usda.gov/faqs/ \#Q1 [https://perma.cc/LJW9-7JBA]. 
enough food calories to sufficiently feed the world today, the impact of issues including poverty, international food policy, diversion of crops out of the food stream, inadequate storage and transportation, and events like war and natural disasters means that hunger exists for about 1 billion people worldwide and current production and distribution systems are insufficient to address that need. ${ }^{11}$

As we look at the challenges of utilizing agriculture and intellectual property to feed the world both now and in the coming years, technology alone is not the answer although it is a necessary tool. I want to focus now less on specific aspects of technology, but on the interactions and limitations of technology related to Consumer Demand, Communication, Collaboration, Consolidation, Conservation and Creativity.

\section{Consumer Engagement-Friend or Foe?}

\section{A. Food Policy Goes Mainstream}

If you would have asked Tom Vilsack when he became Secretary of Agriculture to name a television show in which he would appear as a character, I suspect that South Park would not have made his short list. The same is likely true for Michael Taylor, former deputy commissioner for foods and veterinary medicine for the U.S. Food and Drug Administration (FDA). Yet both of these government officials, or at least cartoon versions of themselves, had starring roles in a 2014 episode of South Park called "Gluten Free Ebola". ${ }^{12}$ The episode covered food policy issues such as gluten-free foods, dietary guidelines, and the effect of food on human health-all in the satirical way that only South Park can manage. ${ }^{13}$

However, this was not South Park's first foray into food policy. A 2010 episode entitled "Medicinal Fried Chicken" irreverently touched on issues such as the impacts of fast food on health, food deserts, and whether or not certain foods or food preparation methods cause cancer. $^{14}$

And yet another of our favorite adult-oriented cartoons centered on an episode more directly related to the genetically engineered food debate. The Simpsons brought "Monsarno" and the world of genetic engineering to our small screens in 2014, with Lisa ultimately conducting research that finds possible benefits to GMOs (counter to her

11. Mark Bittman, How to Feed the World, N.Y. Times, Oct. 20, 2013, at SR9, http://www.nytimes.com/2013/10/15/opinion/how-to-feed-the-world .html?pagewanted=all.

12. See Gluten Free Ebola, WiKIPEDIA, https://en.wikipedia.org/wiki/Gluten_Free_ Ebola [https://perma.cc/KC2L-93EH].

13. Id.

14. See Medicinal Fried Chicken, WiKIPEDIA, https://en.wikipedia.org/wiki/Medi cinal_Fried_Chicken [https://perma.cc/F2TX-SG55]. 
initial concerns). ${ }^{15}$ Unknowingly though, the Simpson family nemesis, Sideshow Bob, is leading the research at Monsarno and focusing not only on genetically modifying food, but his own DNA. ${ }^{16}$

For the USDA Secretary, a Monsanto spoof, and GMOs to hit prime-time pop culture, it highlights the immersion of food policy and technology and related issues into our everyday life. The topics addressed also showcase the divide and debate related to food and agricultural policy issues in our society. Food, and food policy, is everywhere, and you can hardly read a newspaper (print or online) without finding a story that touches on food and agriculture. ${ }^{17}$

Having food policy as a common topic of conversation presents both unique challenges and opportunities when it comes to feeding the world. It is a benefit in that issues surrounding food access, nutrition, and related policies are now being discussed, and there is a heightened level of awareness necessary for action to improve areas of concern. However, considering how far many people are removed from agricultural production, a lack of understanding of agricultural and food processing methods, a growing distrust of both science and media, and the prevalence of pseudo-experts (particularly in the social media sphere), challenges arise when it comes to attempting to reach consensus.

\section{B. Parallel or Intersecting Forces - Consumer Demand and Innovation}

Food is not only something that is necessary to our survival but also a topic that inspires passion. This passion shows when it comes to the debate on issues involving food and technology from production to processing, consumption to preparation. The current debate in the U.S. over what is commonly referred to as "GMO labeling" highlights one of the most divisive issues related to food and technology. While we refer to it as GMO labeling, more technically we are talking about the labeling of foods derived from genetic engineering. ${ }^{18}$

Use of genetically engineered seed crops in the U.S. is not a new issue, as genetically engineered crops have been approved for produc-

15. See generally The Man Who Grew Too Much, WikIPEDIA, https://en.wikipedia .org/wiki/The_Man_Who_Grew_Too_Much [https://perma.cc/9WF6-XNUM].

16. Id.

17. See generally Agriculture and Farming, N.Y. TIMEs, https://www.nytimes.com/ topic/subject/agriculture-and-farming (last visited Feb. 26, 2017) (listing all articles published by N.Y. TIMES related to food and agriculture, averaging at least one per day); Food \& Agriculture, Forbes, https://www.forbes.com/food-agriculture/\#6d7111 713183 (last visited Feb. 26, 2017) (listing all articles published by ForBes related to food and agriculture, including dates of publication).

18. See Glossary of Agricultural Biotechnology Terms, U.S. Dep'T Agriculture, https://www.usda.gov/wps/portal/usda/usdahome?contentid=biotech_glossary.html [https://perma.cc/LBY8-JZSH]. 
tion in the United States for 20 years. ${ }^{19}$ While other countries have taken a more limited approach to approval for production and consumption, adoption in the U.S. of approved crops has been fast and furious. ${ }^{20}$ Between 2000 and 2016, the percent of genetically engineered soybeans planted in the U.S. rose from $54 \%$ of the soybean crop to $94 \%$ of the total soybeans planted in $2016 .{ }^{21}$ Corn shows a more dramatic jump, with only $25 \%$ of the corn planted in 2000 being genetically engineered, rising to $92 \%$ of the total corn crop planted in $2016 .{ }^{22}$ Genetically engineered sugar beet production jumped from $60 \%$ in $2008 / 2009$ to $95 \%$ of total sugar beet production in 2009/ $2010 .{ }^{23}$

Consumers don't generally eat the most common genetically engineered food products directly, but ingredients derived from genetically engineered food products are present in many of the items consumers purchase. It is estimated that between $75-80 \%$ of processed food products contain an ingredient derived from a genetically engineered crop. ${ }^{24}$ FDA's stance on GMO labeling has essentially been the same since its 1992 policy statement: genetic engineering alone is not a material fact that requires a product label. ${ }^{25}$ FDA further states in that guidance that research had not shown "any different or greater safety concern than foods developed by traditional plant breeding." 26

19. Clive James, Brief 51: 20th Anniversary of the Global Commercialization of Biotech Crops (1996 to 2015) and Biotech Crop Highlights in 2015, InT'L SERv. FOR ACQuisition Agri-Biotech ApPlications 1 (2015), http://isaaa.org/resources/publi cations/briefs/51/executivesummary/pdf/B51-ExecSum-English.pdf [https://perma.cc/ QK7L-AWDL].

20. Id.; see also Neil D. Hamilton, Legal Issues Shaping Society's Acceptance of Biotechnology and Genetically Modified Organisms, 6 Drake J. Agric. L. 81 (2001) (providing an overview of the legal issues surrounding use and acceptance of GMOs shortly after their initial introduction); Recent Trends in GE Adoption, U.S. DEP'T Agric. Econ. Res. Serv., https://www.ers.usda.gov/data-products/adoption-of-geneti cally-engineered-crops-in-the-us/recent-trends-in-ge-adoption/ (last updated Nov. 3, 2016) [https://perma.cc/2BSS-7SSX].

21. See Adoption of Genetically Engineered Crops in the U.S., U.S. Dep'T Agric. ECON. RES. SERV., https://www.ers.usda.gov/data-products/adoption-of-geneticallyengineered-crops-in-the-us/ (last updated Oct. 19, 2016) [https://perma.cc/YW6M$\mathrm{Z} 3 \mathrm{MX}]$.

22. Id.

23. See Background: Sugar \& Sweeteners, U.S. Dep't Agric. Econ. Res. Serv., https://www.ers.usda.gov/topics/crops/sugar-sweeteners/background.aspx (last updated Jan. 27, 2017) [https://perma.cc/E5R5-BVGX].

24. How Many Foods Are Genetically Engineered?, uсвіотесн.org, http://ucbio tech.org/answer.php?question $=15$ (last updated Feb. 16, 2012) [https://perma.cc/ 8DZM-RFZ8].

25. Guidance for Industry: Voluntary Labeling Indicating Whether Foods Have or Have Not Been Derived from Genetically Engineered Plants, U.S. Food \& DRUG ADMIN., https://www.fda.gov/Food/GuidanceRegulation/GuidanceDocumentsRegulatory Information/LabelingNutrition/ucm059098.htm (last updated July 1, 2016) [https://per ma.cc/SB7H-9ECV].

26. Id. 
Confusion over what exactly GMOs or genetically engineered foods are and the technology involved can make public discourse on this issue difficult. Depending on the study, anywhere from $66-90 \%$ of American consumers indicate that they want to see GMO labeling on their food. ${ }^{27}$ The reasons for this vary, but in many instances, consumers' fears related to GMO crops are hard to articulate or identify, and GMO avoidance is often spurred by distrust for the safety of the technology ${ }^{28}$ and even for food science. ${ }^{29}$ The 'right to know' movement has been at the forefront of the GMO labeling wars, advocating for a consumer's 'right to know' what is in food products. ${ }^{30}$

Generally "strong consumer interest and the public's 'right to know" is not a sufficient reason to require disclosure of certain information on a food label, absent evidence of safety or health concerns. ${ }^{31}$ Proponents of GMO labeling cite several potential health and safety related concerns to justify this requirement. ${ }^{32}$ Following the approval of GMOs in the U.S., attempts began to require labeling. ${ }^{33}$ With a few exceptions, there was little success despite numerous attempts at the state level through proposed legislation and ballot initiatives to require GMO labeling. ${ }^{34}$

27. See Consumers Want Mandatory Labeling for GMO Foods, CONSUMER ReP. (Dec. 2, 2015), http://www.consumerreports.org/food-safety/consumers-want-manda tory-labeling-for-gmo-foods/ [https://perma.cc/5SN9-XRXA]; see also Monica Anderson, Amid Debate over Labeling GM Foods, Most Americans Believe They're Unsafe, Pew Res. CTr.: Fact TANK (Aug. 11, 2015), http://www.pewresearch.org/fact-tank/ 2015/08/11/amid-debate-over-labeling-gm-foods-most-americans-believe-theyre-un safe/ [https://perma.cc/ZY8D-JG75].

28. See Maria Konnikova, The Psychology of Distrusting G.M.O.s, New Yorker (Aug. 8, 2013), http://www.newyorker.com/tech/elements/the-psychology-of-distrust ing-g-m-o-s [https://perma.cc/UN7Q-9WZE]; see also Why Do People Fear G.M.O.'s?, FreAKonomics: Blog (Feb. 14, 2014, 9:31 AM), http://freakonomics.com/2014/02/14/ why-do-people-fear-g-m-o-s/ [https://perma.cc/9YNP-AEFY].

29. See Brian Kennedy \& Cary Funk, Many Americans Are Skeptical About Scientific Research on Climate and GM Foods, Pew Res. CTr.: Fact Tank (Dec. 5, 2016), http://www.pewresearch.org/fact-tank/2016/12/05/many-americans-are-skeptical-about -scientific-research-on-climate-and-gm-foods/ [https://perma.cc/L6MC-ED68]; see also Brian Kennedy, People Concerned About GM Foods Are Particularly Skeptical of Information from Food Industry, Pew Res. CTR.: FACt TANK (Dec. 9, 2016), http:// www.pewresearch.org/fact-tank/2016/12/09/people-concerned-about-gm-foods-areparticularly-skeptical-of-information-from-food-industry/ [https://perma.cc/FE9JGG8C].

30. See Hamilton, supra note 20, at 96-98 (discussing the consumer's "right-toknow" and labeling movements in the U.S. starting in the early 2000s).

31. See Int'l Dairy Foods Ass'n MIF v. Amestoy, 92 F.3d 67, 73 (2d Cir. 1996).

32. See Labeling of Food Produced with Genetic Engineering, Vt. Stat. Ann. tit. $9, \S 3041$ (2014) (describing reasoning and purpose for law).

33. See Hamilton, supra note 20, at 98.

34. See GMO Labeling - USA, UCBIOTECH.ORG, http://ucbiotech.org/resources/la beling/US_GMO_states/index.html (last updated Mar. 2, 2016) [https://perma.cc/ 98LP-S3E6] (including a list of all related legislation and ballot initiatives in the United States). 
The "right to know" movement saw its first real success with Vermont's passage of Act 120, requiring (among other things), GMO labeling. ${ }^{35}$ The passage of this legislation resulted in litigation seeking to enjoin the law from taking effect, but an attempt to seek a preliminary injunction was unsuccessful. ${ }^{36}$ Some food companies decided to embrace labeling as a way to meet consumer demands and began to take steps to voluntarily provide labeling on a nationwide basis, ${ }^{37}$ while others grudgingly began to adapt product labels to comply with Vermont's law once it became clear that the litigation was not going to prevent the law from taking effect, nor was the push for a federal law going to be successful in time. ${ }^{38}$ Vermont's law, which went into effect on July 1, 2016, was ultimately short-lived, as federal legislation was signed into law by President Obama on July 29, 2016. ${ }^{39}$ The federal law specifically pre-empted any state laws, such as Vermont's, and did not specifically require the same type of written disclosure on the label that many interest groups embraced and was required in the Vermont law. ${ }^{40}$ Instead, the law placed authority with the USDA to develop regulations within two years for a labeling system, but allowed flexibility in the use of disclosure ${ }^{41}$ Instead of the clear and specific language required by the Vermont bill, the standard that many companies continue to voluntary follow, USDA may consider use of a symbol, electronic code, or text to inform consumers of the presence of genetically engineered ingredients. ${ }^{42}$ While there is no current federal standard in place right now and no state laws requiring GMO labeling, if you go to the grocery store, you will still find many

35. Labeling of Food Produced with Genetic Engineering, Vт. Stat. AnN. tit. 9, $\S \S 3041-3048$ (2014). Two other states did successfully pass legislation, but enactment was delayed until certain prerequisite conditions were met regarding adoption of similar labeling laws by surrounding states. See Mandatory Labeling of Genetically-Engineered Food, Seed or Seed Stock. Applicability. Civil Penalty. Regulations, Conn. Gen. Stat. Ann. § 21a-92c (2015); Genetically Engineered Products, Me. Rev. Stat. ANN. tit. 22, §§ 2591-2596 (Supp. 2016).

36. See Grocery Mf'r Ass'n v. Sorrell, 102 F. Supp. 3d 583, 647-48 (D. Vt. 2015); see also Lisa Baertlein, U.S. Food Makers Sue to Stop Vermont's GMO Labeling Law, REuTERs (June 12, 2014, 6:44 PM), http://www.reuters.com/article/vermont-gmoidUSL2N0OT20620140612 [https://perma.cc/AQU6-PBDL].

37. Christopher Doering, Companies Begin Embracing GMO Labeling, DES Moines Reg. (Apr. 2, 2016, 12:04 AM), http://www.desmoinesregister.com/story/ money/2016/04/02/companies-begin-embracing-gmo-labeling/82267542/ [https://perma .cc/SK82-X3RA].

38. Mike Polhamus, Despite Potential Roadblocks, GMO Labeling Law Set to Go into Effect Friday, VTDigger (June 30, 2016, 5:39 AM), https://vtdigger.org/2016/06/ 30/gmo-labeling-law/ [https://perma.cc/APY6-5TH4].

39. 7 U.S.C. $§ 1639 b$ (Supp. 2016); Paul Blake, Obama Signs Bill Mandating GMO Labeling, ABC News (July 29, 2016, 6:10 PM), http://abcnews.go.com/US/obamasigns-bill-mandating-gmo-labeling/story?id=41004057 [https://perma.cc/QVU8-XJB8].

40. See $\S \S 1639 b(\mathrm{~b})(2)(\mathrm{D}),(\mathrm{e})$; see also Consumers Want Mandatory Labeling for GMO Foods, supra note 27.

41. See $\S \S 1639 b(a),(b)(2)$.

42. $\S 1639 \mathrm{~b}(\mathrm{~b})(2)(\mathrm{D})$. 
products on the shelf with labels stating "product of genetic engineering" or "partially produced with genetically engineered ingredients." 43

The requirement to label GMOs is a major shift in the marketplace. Initially, organic food products were the only real option for consumers trying to avoid eating foods including ingredients derived from genetic engineering. ${ }^{44}$ Then a larger segment of the natural/health market began to advertise food products that were not necessarily organic, but were GMO-free. ${ }^{45}$ As consumer demand increased for GMO free products, manufacturers and restaurants responded. Companies like Ben \& Jerry's and Chipotle announced they would be making a switch to all non-GMO ingredients. ${ }^{46}$ Other companies started making adjustments to ingredients and sources more quietly, in some cases to avoid having to label the foods when Vermont's law was imminent, others to reflect what they saw as meeting customer interests. ${ }^{47}$ For example, Hershey decided to stop using sugar produced from sugar beets in its chocolate and candy products, making a switch to sugar derived from sugar cane, a non-GMO sourced sugar option. ${ }^{48}$ Nestlé, Dannon, and Del Monte all made similar pledges for some or all of their products, including Dannon going so far as to say it also would require that the milk it purchases be from cows fed from non-GMO sources. ${ }^{49}$

43. See generally Dan D'Ambrosio, Obama Signs National GMO Labeling Law; VT Law Now Moot, Burlington Free Press (Aug. 1, 2016, 4:17 PM), http://www .burlingtonfreepress.com/story/news/2016/08/01/obama-signs-national-gmo-labelinglaw-vt-law-now-moot/87922974/ [https://perma.cc/FQB7-49UZ] (discussing the continued use of labels on products).

44. See Agric. Mktg. Serv., Can GMOs Be Used in Organic Products?, U.S. DeP't Agriculture (May 2013), https://www.ams.usda.gov/sites/default/files/media/ Can\%20GMOs\%20be\%20Used.pdf [https://perma.cc/X6SD-3NEF].

45. See Helena Bottemiller, With Recent Victories, Movement to Label GMOs Gains Steam, Food SAFETy News (June 27, 2013), http://www.foodsafetynews.com/ 2013/06/movement-to-label-gmos-gaining-steam/\#.WK5z7Y-cHIU [https://perma.cc/ 2FQX-FQWR].

46. See Our Non-GMO Standards, BEN \& JeRry's, http://www.benjerry.com/values/issues-we-care-about/support-gmo-labeling/our-non-gmo-standards [https://perma .cc/T6AS-Z4LT]; G-M-Over It, CHIPOTLE, https://chipotle.com/gmo [https://perma.cc/ LXC7-YSKW].

47. Jane Lindholm, Some Food Companies Are Quietly Dumping GMO Ingredients, NAT'L PuB. Radio (July 22, 2014, 4:44 AM), http://www.npr.org/sections/thesalt/ 2014/07/22/333725880/some-food-producers-are-quietly-dumping-gmo-ingredients [https://perma.cc/QLD9-M6HZ].

48. Tom Meersman, Hershey Dumps Sugar Beets Because of GM Concerns, STAR Tribune (Dec. 27, 2015, 2:27 PM), http://www.startribune.com/hershey-dumps-sugarbeets-because-of-gm-concerns/363498311/ [https://perma.cc/D3NH-AQEG].

49. See, e.g., Jim Cornall, Dannon 'Pledge' to Declare GMOs with Natural Ingredients Push, DAIRYREPORTER.COM (Apr. 28, 2016), http://www.dairyreporter.com/ Manufacturers/Dannon-pledge-to-declare-GMOs-with-natural-ingredients-push/?p2 [https://perma.cc/KE4H-SJAH]; ThE DANnON PledGe, http://www.dannonpledge .com/ (last visited Feb. 26, 2017); On GMOs, NestLÉ USA, http://www.nestleusa.com/ about-us/gmo [https://perma.cc/Y7AP-B75N]; Lucinda Shen, Del Monte Is Making This Huge Change to Its Products, Fortune (Mar. 29, 2016), http://fortune.com/2016/ 03/29/del-monte-natural-products/ [https://perma.cc/7AV3-BYU4]. 
The GMO labeling issue highlights the debate over what the true impact is of genetically engineered crops in agricultural production. Farmers and farm organizations taking issue with moves like that of Dannon argue that going back to non-GMO crops will reduce efficiencies, decrease production, and require increased use of chemicals, effectively removing advancements of the last 20 years. ${ }^{50}$ Dannon's response did not contend that GMOs were unsafe, and noted that the company believed successful, sustainable agricultural practices were possible both with and without the use of GMOs. ${ }^{51}$ The decision by Dannon, the company stated, was a response to consumer demand. ${ }^{52}$

U.S. consumer perception of GMOs and foods derived from genetically engineered material is largely negative..$^{53}$ Even citizens who regularly consume these products often indicate some level of uncertainty or confusion. ${ }^{54}$ While the science still largely indicates that GMOs and genetically engineered food products are safe for consumption and the environment, ${ }^{55}$ the consumer movement against GMOs is strong and, as discussed, is having a significant impact on choices made by food manufacturers.

50. Forrest Laws, Farm Groups Take Issue with Dannon's Anti-GMO Stand, Delta Farm Press (Oct. 25, 2016), http://www.deltafarmpress.com/technology/farmgroups-take-issue-dannon-s-anti-gmo-stand [https://perma.cc/VAF5-B5D3].

51. See The Dannon Co., Dannon's Response to Unfounded Accusations About the Company's Pledge to Sustainable Agriculture, Naturality and Transparency, PR NewswIRE (Oct. 17, 2016, 6:33 PM), http://www.prnewswire.com/news-releases/dannons-re sponse-to-unfounded-accusations-about-the-companys-pledge-to-sustainable-agricul ture-naturality-and-transparency-300346216.html [https://perma.cc/3JBF-Q4G2]. See also Mike Opperman, GMO Debate Is About Consumers, Not Sustainability, Farm JournaL's Milk: BlOG (Oct. 18, 2016), http://www.milkbusiness.com/blog/gmo-de bate-about-consumers-not-sustainability [https://perma.cc/M9B4-FXPM].

52. The Dannon Co., supra note 51

53. See, e.g., Cary Funk \& Lee Rainie, Chapter 6: Public Opinion About Food, Pew Res. CTR. (July 1, 2015), www.pewinternet.org/2015/07/01/chapter-6-public-opinion-about-food/ [https://perma.cc/6V4H-J4YZ]; Cary Funk \& Brian Kennedy, Public Opinion About Genetically Modified Foods and Trust in Scientists Connected with These Foods, Pew Res. Ctr. (Dec. 1, 2016), http://www.pewinternet.org/2016/12/01/ public-opinion-about-genetically-modified-foods-and-trust-in-scientists-connectedwith-these-foods/ [https://perma.cc/TN22-ZQZT]; Cary Funk, 5 Key Findings on What Americans and Scientists Think About Science, Pew Res. Ctr.: Fact Tank (Jan. 29, 2015), http://www.pewresearch.org/fact-tank/2015/01/29/5-key-findings-science/ [https://perma.cc/4G3D-VFRB]. But see Nicholas Staropoli, Pew Survey: Americans Don't Trust Scientists on GMOs, but Are Warming to GM Foods, GeneTIC Literacy Project (Dec. 1, 2016), https://www.geneticliteracyproject.org/2016/12/01/pew-sur vey-americans-dont-trust-scientists-gmos-warming-gm-foods/ [https://perma.cc/ 8KML-MQPY].

54. Id.

55. See generally The Nat'l Academies of Sciences, Eng'g, \& Med., GenetiCAlly Engineered Crops: Experiences and Prospects (May 2016), http://nassites.org/ge-crops/2016/05/16/report-in-brief/ [https://perma.cc/HNS9-4EYN]; A. L. Van Eenennaam \& A. E. Young, Prevalence and Impacts of Genetically Engineered Feedstuffs on Livestock Populations, 92 J. AnIMAL SCI. 4255 (2014) (reviewing studies related to feeding GMOs to livestock over long term and finding no elevated health risks). 
What does this have to do though with technology and innovation in agriculture and feeding the world? As we look towards the development and use of technology in the future, we need to recognize that consumers are driving major changes in food manufacturing and food ingredient decisions. As noted in the next Part, the reasons behind these consumer movements vary, but for many there is a real distrust not just for the science but for the biotech industry as well. ${ }^{56}$ It is hard to say if the impacts we are seeing now on the industry will have longterm effects. It is possible this is a long-lasting shift on use of GMOs, but it is possible as well that other factors, such as increased food costs or less focus on the issue once the federal labeling program is in place, will reduce consumer interest in the issue and allow companies to quietly return to using GE ingredients.

But thinking more broadly, what impact can a coordinated consumer movement focused on eliminating something like genetically engineered foods from the marketplace have on agricultural technology as a whole? If consumers refuse to buy food products derived from whatever the newest agricultural technology may be, and food manufacturers respond to those demands by adjusting ingredients or food sources, there is the potential for a chilling effect on the biotech industry.

Developing GE crops is a long and expensive process. ${ }^{57}$ Receiving a return on investment is key to continuing the research and development process. ${ }^{58}$ If the market for certain technologies drops in the U.S. marketplace, companies may become more hesitant to introduce new technologies into the production stream, or to begin developing new technologies in the first place. While there is debate regarding the benefits of GE crops related to increased yield, decreased chemical use, and overall sustainability, ${ }^{59}$ genetic engineering is also a tool in

56. See, e.g., Funk \& Kennedy, supra note 53; Cary Funk \& Brian Kennedy, The New Food Fights: U.S. Public Divides over Food Science, Pew Res. Ctr. (Dec. 1, 2016), http://www.pewinternet.org/2016/12/01/the-new-food-fights/ [https://perma.cc/ H2ZL-ZX9Z] (finding that trust in information from food industry leaders is lower for those deeply concerned about the issue of GM foods); Jan M. Lucht, Public Acceptance of Plant Biotechnology and GM Crops, 7 VIRUSEs 4254 (2015) (discussing consumer perceptions of risks and benefits of GMOs, including the "general climate of distrust").

57. See, e.g., Wendelyn Jones, Comment to How Much Time Does It Take and How Much Does It Cost to Successfully Develop a Hybrid with One or More Transgenic Traits from Conception to Commercial Release?, GMO ANSwERs (Nov. 7, 2013, 3:10 PM), https://gmoanswers.com/ask/how-much-time-does-it-take-and-how-muchdoes-it-cost-successfully-develop-hybrid-one-or-more [https://perma.cc/XQ3H2RXK]; Nicholas Kalaitzandonakes et al., Compliance Costs for Regulatory Approval of New Biotech Crops, 25 Nature Biotechnology 509, 509 (2007).

58. See, e.g., Kalaitzandonakes et al., supra note 57, at 510-11.

59. See Danny Hakim, Doubts About the Promised Bounty of Genetically Modified Crops, N.Y. Times (Oct. 29, 2016), https://www.nytimes.com/2016/10/30/business/ gmo-promise-falls-short.html?_r=1 [https://perma.cc/CJB9-QECC]; but see Daniel R. Pearson, NYT Article Understates the Benefits of GMOs, CATO Inst.: CATO AT 
efforts to increase the nutritional benefits of certain crops or to adapt to changing climate conditions. ${ }^{60}$ More importantly, the impact could easily extend beyond just the use of genetic engineering. Distrust of biotech companies, and less trust in scientific studies and reports, means that any new technology entering the market has the potential to be the next "GMO issue" for consumers. ${ }^{61}$

Conversely, this focus on GMOs may also inspire companies to rethink the focus of research and development and to address consumer interests. One example may be the Arctic Apple, a product released in February 2017 in select stores as a market test. ${ }^{62}$ While most genetically engineered crops are marketed to farmers, the Arctic Apple is one of the first to be developed and marketed to consumers. ${ }^{63}$ The Arctic apple is not a traditional transgenic food, in that there is no insertion of foreign species in the DNA of the apple. ${ }^{64}$ Instead, scientists were able to "silence" the gene that causes apples to turn brown after being cut. ${ }^{65}$ Sliced apples have been on the market, but this new technology "match[es] the industry norm of not browning for three weeks after slicing but without using flavor-altering, chemical additives that the rest of the fresh-sliced apple industry uses." 66 It remains to be seen if consumers will embrace this product, one that may provide consumers with the direct benefit of disputed type of technology. ${ }^{67}$

In short: If consumers refuse to purchase certain food products, food manufacturers may, in turn, refuse to purchase certain crops. As a result, agricultural producers could seek different input suppliers to meet market demands, potentially meaning decreased return on in-

Liberty Blog (Nov. 2, 2016, 1:42 PM), https://www.cato.org/blog/nyt-article-understates-benefits-gmos [https://perma.cc/NDB3-Z5YW].

60. See Matt Weiser, Scientists Think GMO Crops May Help Us Deal with Climate Change, Pub. Radio InT'L (Jan. 13, 2016, 9:15 AM), https://www.pri.org/stories/201601-13/researchers-around-world-are-exploring-how-gmo-technology-might-boost-

food [https://perma.cc/C62P-CV7T]; Why Golden Rice, Is There a Need for It?, Golden Rice Project, http://www.goldenrice.org/Content3-Why/why.php [https:// perma.cc/F54F-CGTU].

61. See Antonio Regalado, Here Come the Unregulated GMOs, MIT TECH. REv. (Apr. 15, 2016), https://www.technologyreview.com/s/601285/here-come-the-unregulated-gmos/ [https://perma.cc/9FAY-XFL3] (discussing the reluctance of market developers to release mushroom using new technology due in part to consumer reactions).

62. Dan Wheat, First GMO Apple Slices to Go on Sale in the Midwest, Cap. Press (Jan. 9. 2017, 5:01 PM), http://www.capitalpress.com/Orchards/20170109/first-gmo-apple-slices-to-go-on-sale-in-midwest [https://perma.cc/S6LC-YC55].

63. Grant Gerlock, Why the Arctic Apple Means You May Be Seeing More GMOs at the Store, NAT'L Pub. Radio (Feb. 1, 2017, 3:10 PM), http://www.npr.org/sections/ thesalt/2017/02/01/512633781/why-the-arctic-apple-means-you-may-be-seeing-moregmos-at-the-store [https://perma.cc/AN6X-P55U].

64. Id. See also discussion infra Section III.B.

65. See Gerlock, supra note 63

66. See Wheat, supra note 62.

67. See Luis Herrera-Estrella \& Ariel Alvarez-Morales, Genetically Modified Crops: Hope for Developing Countries?, 2 EMBO ReP. 256 (2001). 
vestment (and less incentive to continue developing certain traits, crops, or technologies) for biotech and seed companies.

It has become clear that even if government regulators allow the use of new technology in food products, and the majority of the scientific evidence indicates the technology is safe, there is no guarantee that the technology will be accepted at all levels of the marketplace. The impact that consumer demand can have on the adoption and use of technology cannot be discounted or ignored.

The GE/GMO debate highlights an emerging voice that is finding a way to make itself heard in the food policy arena-the voice of the consumer. ${ }^{68}$

\section{Express Yourself-Communication Challenges}

\section{A. GMOs-Communication Case Study}

A key point of the above discussion regarding consumer impacts on the food industry, and potentially biotechnology, is the importance of communication. Consumers, globally, have become more interested and aware in more than just the nutritional value of food, but also in how it was produced. ${ }^{69}$ The anti-GMO movement is not just limited to the United States. Over 60 countries across the world require some sort of GMO label on food products, and 3 countries have fully banned production and imports. ${ }^{70}$ Many argue that a major part of the distrust of biotech companies and scientific studies related to GMOs may be traced back to the failure to include consumers in the primary marketing plan when GMOs were first introduced into the U.S. market. Looking at this from a communication standpoint may help highlight the importance of good communication between all parties in the food chain, consumers-to-producers, when it comes to the adoption and use of technology in our food system.

Companies, when GMOs were first approved and introduced to the market, focused educational and marketing efforts on farmers and regulators. The goal was to educate farmers about perceived environmental benefits and efficiencies that these crops could bring to their

68. See About, Plate Union, http://www.plateoftheunion.com/about/ [https://per ma.cc/6CXR-9AWN]; Helena Bottemiller Evich, Soda-less in Seattle? Mayor Proposes Soda Tax, Politico (Feb. 22, 2017, 10:00 AM), http://www.politico.com/tipsheets/ morning-agriculture/2017/02/soda-less-in-seattle-mayor-proposes-soda-tax-218857

[https://perma.cc/7K3D-FRTS] (noting that Food Policy Action and EWG were "look[ing] to get consumers engaged on farm bill" and discussing "Plate of the Union" campaign).

69. Id.

70. See Genetically Engineered Food Labeling Laws, CTR. FOR Food SAFETy, http://www.centerforfoodsafety.org/ge-map/ [https://perma.cc/997F-QMRQ]. In addition to labeling, some countries will only allow imports, but not production of GMO crops. See Global Approvals of GMO Crops, GMO ANSWERs, https://gmoanswers.com/ global-approvals-gmo-crops [https://perma.cc/2L2C-K2C8]; see also Hamilton, supra note 20 , at 110-13 (discussing global regulation issues in early 2000s). 
operations in an effort to encourage adoption, while also persuading regulators the products were safe in an effort to seek government approval. ${ }^{71}$ Once approved by all required agencies, including FDA approval for use in food and feed products, GMO crops were generally intermingled with traditional crops, meaning companies began using them in food manufacturing, unless specific steps were taken to find non-GMO products. ${ }^{72}$ Consumers were, in large part, left out of this equation. ${ }^{73}$

As consumer awareness grew regarding use of genetic engineering in food crops, the lack of consumer-focused education meant the door was open for information from a variety of sources to have increased influence. ${ }^{74}$ The biotech industry's perceived failure, or reluctance, to provide information to consumers increased consumer skepticism regarding safety of GMO products. ${ }^{75}$ One of the first comprehensive industry-wide targeted consumer education campaigns was launched in 2014 with the GMO Answers website. ${ }^{76}$ However, given the current perceptions of GMOs in the U.S., it may be an example of too little, too late when it comes to changing consumer views.

Communication also becomes key in how we use and understand information. For example, some argue that the "right to know" debate can also induce more confusion about the food label and the science behind biotechnology. ${ }^{77}$ Research indicates the great divide between the average consumer perception about the safety of GMOs, and the perceptions of the scientific community. ${ }^{78}$ As new technology is being

71. See generally Peter W.B. Phillips \& David Corkindale, Marketing GM Foods: The Way Forward, 5 AgBioForum 113 (2002).

72. See Hamilton, supra note 20 at 98-99 (providing overview of regulatory process).

73. Dan Flynn, Plant Biotechnology Industry Rolls Out Site to Address Top Consumer Questions, Food SAFETY News (Mar. 20, 2014), http://www.foodsafetynews .com/2014/03/plant-biotechnology-industry-wants-to-engage-with-consumer-with-an swers-to-their-questions/\#.WK3pZk2FObg [https://perma.cc/MM78-76SP].

74. An Acknowledgement for Change, GMO ANSwERs, https://gmoanswers.com/ about [https://perma.cc/8684-3PJG].

75. See, e.g., Why Are Companies Against GMO Labeling?, GMO Answers (Dec. 26, 2013, 5:55 PM), https://gmoanswers.com/ask/why-are-companies-against-gmo-la beling-if-its-safe-they-shouldnt-care-whether-they-have-label-it [https://perma.cc/ RTQ9-X8KJ]; Should Companies Be Required to Label Genetically Modified Foods?, Wall St. J. (July 12, 2015, 11:10 PM), https://www.wsj.com/articles/should-compan ies-be-required-to-label-genetically-modified-foods-1436757040 [https://perma.cc/ Q369-BCBQ].

76. See Flynn, supra note 73; see also An Acknowledgement for Change, supra note 74 .

77. Mary Clare Jalonick, Debate over Genetically Modified Foods Continues Amid Confusion, PBS Newshour, (May 17, 2014, 11:16 AM), http://www.pbs.org/newshour /rundown/national-debate-genetically-modified-foods-continues/ [https://perma.cc/ AS8A-3APK].

78. See Monica Anderson, Amid Debate over Labeling GM Foods, Most Americans Believe They're Unsafe, Pew Res. CTr.: Fact Tank (Aug. 11, 2015), http://www .pewresearch.org/fact-tank/2015/08/11/amid-debate-over-labeling-gm-foods-most-a mericans-believe-theyre-unsafe/ [https://perma.cc/VC9P-RU29]. 
developed within the agricultural sector, communication strategies will need to be developed to educate adopters and users of the technology, regulators, and consumers, among others. ${ }^{79}$ Learning from experiences with adoption of GMOs and consumer education are important, particularly as we look to some of the emerging technologies currently in production.

\section{B. Same Story, Different Technology?}

As noted above, the biotech industry joined together in 2014 to launch GMO Answers, a website "created to do a better job answering your questions - no matter what they are - about GMOs." ${ }^{80}$ As part of the description of the site and why it was created, the industry specifically stated, "we acknowledge that we haven't done the best job communicating about [GMOs]." ${ }^{81}$ Based on the current perception of GMOs and trends in the market, questions remain about what the future holds for this specific technology. Based on what the industry has learned regarding GMOs in the marketplace, we can hope that, as science and technology continue to evolve and new advances are made, the industry will better communicate the science, benefits, advantages, potential risks, testing, and regulatory process to those outside the industry Recent comments though, related to emerging technologies, make me worry that the industry has not necessarily learned from past missteps.

Specifically, the new technology I refer to is commonly referred to as CRISPR or CRISPR-Cas9. CRISPR technology differs from genetic engineering in that it does not involve moving genes from one species to another. ${ }^{82}$ Instead, CRISPR technology, in simple terms, is a form of gene editing where scientists can edit a gene to eliminate a particular trait (silencing it) or edit out an undesirable trait and "repair" the gene with a version that does not include the undesirable trait (but already found in the same species). ${ }^{83}$ Reading about this

79. See, e.g., Keith Robinson, Communicating the Science, Agricultures Mag., Summer 2014, at 16, available at https://ag.purdue.edu/agricultures/Pages/Summer 2014/Agricultures_Summer_2014.pdf [https://perma.cc/8WYM-HT3A]; HoLLY Rhodes \& Keegan Sawyer, Nat'l Research Council of the Nat'l Academies, How People Think (About Genetically Modified Organisms), in Public Engagement on Genetically Modified Organisms: when Science and Citizens Connect: Workshop Summary 5, 8 (2015); Keith Kloor, The Tricky Terrain for GMO Communication, Discover: COLlide-A-SCAPE (Jan. 16, 2015, 10:31 AM) http:/ /blogs.discovermagazine.com/collideascape/2015/01/16/tricky-terrain-gmo-communica tion/\#.WLCpxE2FNmM [https://perma.cc/N28K-2CVM].

80. An Acknowledgement for Change, supra note 74.

81. Id.

82. What Are CRISPR/Cas9 and Other New Breeding Technologies (NBTs)?, GENetiC LiteraCy Project, http://gmo.geneticliteracyproject.org/FAQ/what-is-crisprcas9-and-other-new-breeding-technologies-nbts/ [https://perma.cc/JP6S-GZG9].

83. Id. 
technology is fascinating, and it is quickly becoming a focus of scientists across many specialties, including plant genetics. ${ }^{84}$

It would not be inappropriate for a person to think that when foods are developed from plants using this technology, they would in turn be required to be labeled as such. After all, we are editing the sequence of a gene and making changes to the genetic structure-something that, for those of us that do not come from scientific backgrounds, does not sound all that different from genetic engineering or other forms of regulated technology.

While it might not be inappropriate to assume that these foods require labeling, under current regulations and standards, that assumption is not necessarily correct. In early 2016, the USDA announced it would not need to regulate and approve the cultivation of a mushroom developed with CRISPR technology. ${ }^{85}$ This mushroom, with a gene edited to "turn off" enzymes that cause the mushrooms to brown, is now able to be produced without further review by the USDA. ${ }^{86}$ In this instance, regulation was avoided because it did "not contain foreign DNA from 'plant pests' such as viruses or bacteria." ${ }^{87}$

That does not, however, mean there is no potential government regulation related to this method. While the USDA has indicated there is not a need for approval prior to cultivation, the FDA is currently evaluating what regulatory process is most applicable to ensure the health and safety of food products derived from gene editing processes. ${ }^{88}$ When it comes to plant products, the FDA is currently gathering the scientific data needed to determine if gene editing can cause potential health or safety risks to consumers that would not be found if they were consuming plants bred using traditional methods. ${ }^{89}$ When it comes to using gene editing in animals, the FDA is taking a much tougher regulatory stance, essentially regulating the use of gene editing in animals the same as it would for a new animal drug. ${ }^{90}$ The argu-

84. Id.

85. Emily Waltz, Gene-edited CRISPR Mushroom Escapes US Regulation, 532 NATURE 293, Apr. 14, 2016, http://www.nature.com/polopoly_fs/1.19754!/menu/main/ topColumns/topLeftColumn/pdf/nature.2016.19754.pdf [https://perma.cc/89CA-AZV $\mathrm{F}]$.

86. Id.

87. $I d$.

88. Robert M. Califf \& Ritu Nalubola, FDA's Science-based Approach to Genome Edited Products, U.S. Food \& Drug Admin.: FDA Voice Blog (Jan. 18, 2017), https://blogs.fda.gov/fdavoice/index.php/2017/01/fdas-science-based-approach-to-gen ome-edited-products/ [https://perma.cc/X936-U9JJ].

89. Id.

90. Id. It is not just consumers that have concerns about the need for more research of the use of CRISPR, specifically when it is used in areas beyond agriculture. See Jennifer Kahn, The Crispr Quandary, N.Y. Times Mag., Nov. 15, 2015, at MM63, https://www.nytimes.com/2015/11/15/magazine/the-crispr-quandary.html?_r=0. Environmental concerns regarding impacts on the ecosystem also exist. See Laura Lloyd, CRISPR-Cas9 Gene-editing Is Promising for Ag Sector, Food Bus. News (Feb. 20, 2017), http://www.foodbusinessnews.net/articles/news_home/Research/2017/02/ 
ment for doing so is that gene editing essentially alters the basic structure of the animal, thus falling under the drug classification. ${ }^{91}$

While the government sorts out how to handle new and evolving technology, as products do start to come to market, and several are poised to do so in the near future, it will be interesting to see how biotech companies choose to market and communicate about this CRISPR technology. On one hand, companies want (and need) to avoid a consumer movement against this new technology. CRISPR offers an advantage over the science behind most GMOs in that there is not a need to introduce foreign material into a species. ${ }^{92}$ That being said, we are still talking about manipulating the genes of a plant or an animal, and that alone may raise the concerns of consumers, particularly with the growing trend to distrust science. ${ }^{93}$

So what's a company to do? Would foods derived from technology such as CRISPR be required to carry a GMO label? The answer to that is not clear. Under most definitions of bioengineered foods, CRISPR or at least not all of the variants of this technology, does not clearly fall into that category. ${ }^{94}$ As the USDA develops regulations pursuant to the new federal GMO labeling law, how it defines "bioengineered" food products will be important in determining not just what products containing GMOs need to be labeled, but also to what extent other technologies will be included in the labeling requirements. ${ }^{95}$

Some companies believe the fact that CRISPR is not generally regulated the same as GMOs and may not need to be labeled as such under current international and pending U.S. standards is a benefit to the technology. ${ }^{96}$ For companies seeking to quickly bring products to the market a different regulatory structure would be a huge benefit. ${ }^{97}$

CRISPRCas9_geneediting_is_prom.aspx?ID=\%7B9D27A90B-9812-47BE-B138-6BB DF7830415\%7D [https://perma.cc/XFL2-ZLXJ].

91. See Califf \& Nalubola, supra note 88. See also Federal Food, Drug, and Cosmetic Act, 21 U.S.C. $§ 321(\mathrm{~g})(1)(\mathrm{c})$ (2012).

92. See Dan Charles, Will Genetically 'Edited' Food Be Regulated? The Case of the Mushroom, NAT'L PuB. Radio (Apr. 15, 2016, 12:41 PM), http://www.npr.org/sec tions/thesalt/2016/04/15/474358416/will-genetically-edited-food-be-regulated-the-caseof-the-mushroom [https://perma.cc/4SHK-V3S2]; see also Why Do People Fear G.M.O.'s?, supra note 28 (discussing the irrational fear of the unnatural and providing genetically engineered hybrid plants as an example).

93. See, e.g., Konnikova, supra note 28; What Are CRISPR/Cas9 and Other New Breeding Technologies (NBTs)?, supra note 82; Kennedy \& Funk, supra note 29.

94. Simon J. Elliott, GMO Food Labeling and CRISPR-modified Foods, NAT'L L. REV. (Sept. 22, 2016), http://www.natlawreview.com/article/gmo-food-labeling-andcrispr-modified-foods [https://perma.cc/ZUG3-62GY].

95. Id.

96. See How Are Governments Regulating CRISPR and New Breeding Technologies (NBTs)?, Genetic Literacy Project, http://gmo.geneticliteracyproject.org/ FAQ/how-are-governments-regulating-crispr-and-new-breeding-technologies-nbts/ [https://perma.cc/DDA5-9TJD].

97. See id. (discussing the low barrier of entry for products created through gene silencing). 
But, for biotech companies to operate under a "we don't need to tell" policy, they are simply setting themselves up for the next anti-GMO movement. As companies begin to use CRISPR in the agriculture sector, at the same time they are exploring science, communications strategies should be developed. Transparency is being demanded by consumers, and providing that through effective, honest, and open dialogue is something I believe is going to be necessary to succeed in this arena.

If nothing else, the GMO debate should have taught the industry that a targeted strategy needs to be developed to help increase acceptance of this technology as it enters the marketplace and ultimately, our plates. We know from past experience that scientific studies regarding health and safety alone are not enough to convince many, ${ }^{98}$ and attempting to force products through the food chain and to consumers will not be successful either. If attempts are made to avoid any sort of labeling or disclosure, biotech companies will likely find themselves facing another round of state legislation related to disclosure and labeling of food products, just with a different technology at issue.

\section{Building Relationships and Understanding Needs}

Feeding the world is not a one industry, one country, or one issue challenge. Because of this, it requires strong communication efforts on multiple levels. Technology and innovation may develop truly great products or practices, but if they are not meeting producer needs or understanding the concerns of others within the marketplace, adoption of the technology may be limited. The demand for information is impacting how the innovators, the producers, the manufacturers, government, and consumers work together. This is particularly true as we look to technology, in some shape or form, to help increase production in developing countries in the quest to feed the world.

Communication is what will help those seeking to reduce hunger to understand big picture challenges and the multiple ways people in those countries need assistance. ${ }^{99}$ It will also help address cultural changes or barriers related to the adoption of technology. ${ }^{100}$ Supporting farmers and reducing hunger in developing countries is not just an issue of increasing production, but one that is much broader in terms

98. See Dan Grant, Communication Key to Winning GMO Debate, FARMWEeKNow.COM (Nov. 26, 2014), http://farmweeknow.com/story-communication-key-win ning-gmo-debate-1-120825 [https://perma.cc/7CKD-2D4E].

99. Dan Jacobi \& Caitlin Andersen, Agriculture and the Law: Can the Legal Profession Power the Next Green Revolution?, 21 Drake J. Agric. L. 177, 180-85 (2016) (discussing several issues facing farmers in the developing world).

100. See Amie Tsang \& Cao Li, In Push for G.M.O.s, China Battles Fears of 8Legged Chickens, N.Y. Times, Oct. 20, 2016, at B1, https://www.nytimes.com/2016/10/ 20/business/dealbook/chinas-genetically-modified-food-dreams-face-bitter-harvest .html?_r=0 (addressing cultural fears within China related to consumption of GMOs). 
of access to land and inputs, infrastructure and government policies. ${ }^{101}$ Communicating with each other in respectful and productive ways will help bring a better understanding of the issues that need to be addressed, unique challenges that exist in different parts of the world when it comes to addressing those issues, and understanding the values and individuality of those you are working with and working to support. ${ }^{102}$

\section{Collaborate and Listen-Building Relationships}

When we talk about consumer demand and also the importance of communication, another factor that is closely related and required for success is collaboration. In order to feed the world, there does need to be an increase in production on some level, particularly in developing countries where populations will also be growing most rapidly. ${ }^{103}$ But while technology is a tool to help increase production, there are numerous cultural, regulatory, and social challenges that can undermine the success of even the best technology and agricultural production methods. For example, technology involving new crop varietals will have limited impact if high levels of poverty prevent farmers from getting access to needed inputs. ${ }^{104}$ Food products developed using technology increasing the value of a particular nutrient will not address health concerns if consumers will not eat it. ${ }^{105}$ Investments in farming practices will be limited if producers do not have security in land ownership or tenure. ${ }^{106}$ Increases in production will not get to those that need it if there is insufficient storage or transportation for crops postharvest. ${ }^{107}$

The challenges noted above are not minor, easy to address, or small in scale, and each community will have unique aspects to common concerns. When it comes to attempting to overcome or address these

101. See Jacobi \& Andersen, supra note 99, at 180-85.

102. See generally Samantha Hautea, Programs Empower Women Farmers Around the World, Cornell Chron. (Oct. 14, 2016), http://www.news.cornell.edu/stories/ 2016/10/programs-empower-women-farmers-around-world [https://perma.cc/B3EKV8V7] (noting that men and women prefer different traits in cassava, an issue to be considered when working to encourage adoption of new technology).

103. U.N. Dep't of Econ. \& Soc. Affairs, supra note 1.

104. See Food \& Agric. Org. of the U.N., Int'l Fund for Agric. Dev. \& World Food Programme, Reducing Poverty and Hunger: The Critical Role of Financing for Food, Agriculture and Rural Development 4 (2002), available at ftp://ftp.fao.org/docrep/fao/ 003/y6265e/y6265e.pdf. See also Allan Mauro V. Marfal, Sustainable Environment Eyed to Raise Farmers' Quality of Life, Republic Phil. Dep't Sci. \& Tech. (Oct. 13, 2016), http://dost.gov.ph/knowledge-resources/news/45-2016-news/1052-sustainableenvironment-eyed-to-raise-farmers-quality-of-life [https://perma.cc/KF4Z-ND5U].

105. See Tsang \& Li, supra note 100 (discussing Chinese fears regarding GMOs and food safety).

106. See Jacobi \& Andersen, supra note 99, at 180-81.

107. Id. at $184-85$. 
barriers, success will require coordinated collaboration between a variety of partners.

Some of the issues are more legal in nature and require government action and strong policies: land ownership rights, reliable and accessible legal system for contracts or disputes, protection of intellectual property rights, and access to markets. ${ }^{108}$ Other issues can be addressed through the action of private and public organizations, nonprofits, or NGOs, such as educational programs on production methods and the use or development of certain technologies. ${ }^{109}$ Technology is also key to helping share information amongst farmers in developing countries, where technology is not nearly as accessible as in more developed countries. ${ }^{110}$ The ability to learn from each other and share information with peers locally and across the globe, or connect with experts quickly to address concerns, can help improve production and also build markets and other opportunities. ${ }^{111}$ Improvements in communication systems and access to technology can make collaboration possible between individuals and organizations across the world. ${ }^{112}$ Relationships at local, state and international levels will be key to ensuring that the underlying programs are in place that will allow new programs and technologies to improve production in developing nations.

Collaboration is also important to the developed world as well. When it comes to technology, partnerships among organizations may be key to successful adoption and acceptance. Collaboration can help develop technology aimed at reducing certain environmental impacts of farming, as growers, industry and others work together to find sustainable solutions. ${ }^{113}$ Collaboration is also necessary when it comes to the regulatory process, bringing together all involved to ensure an understanding of issues and concerns as well as the science behind the technology, and developing protocol that encourages innovation while also ensuring the health and safety of consumers. It is not an easy challenge for regulators to try to develop regulations in the biotech area that are narrow enough to be relevant, effective and usable, but also broad enough to keep up with the speed at which science is evolving and new technologies emerging.

108. Jacobi \& Andersen, supra note 99, 180-85. See also Marfal, supra note 104.

109. See Hautea, supra note 102.

110. Meera Senthilingam, The Tech Solutions to End Global Hunger, CNN, http:// www.cnn.com/2017/02/23/health/tech-apps-solving-global-hunger-famine/ [https://per ma.cc/NVT7-PDFY] (last updated Feb. 24, 2017).

111. $I d$.

112. $I d$.

113. See Environmentalists, Agriculture Industry Team up on Minnesota Water Quality, StarTribune (May 27, 2016, 6:53 PM), http://www.startribune.com/environ mentalists-agriculture-industry-team-up-on-minnesota-water-quality/381172521/

[https://perma.cc/HW3Y-RFJY] (highlighting the partnership between farmers, environmentalists, industry and government to address water quality issues in Minnesota). 


\section{Industry Consolidation-InNOVAtion Necessity OR INNOVATION KILLER?}

We cannot talk about biotechnology without addressing the issue of consolidation within the agricultural industry. At the time of writing, three major mergers are pending that have the potential to dramatically change the agricultural input market and agricultural biotechnology. Five of the six biggest involved in seed and chemical sales are looking to merge and leave three major players in this market. ${ }^{114}$ The proposed partnerships pair Dow and DuPont, Monsanto and Bayer, and Syngenta and ChemChina. ${ }^{115}$ Because of the nature of these businesses, the core elements of food production, all Americans (really all humans given the international scope) are affected on a base level by the impact these mergers could have on the food industry and food policy. ${ }^{116}$ The proposed mergers have raised the concerns of U.S. and international regulators, as well as consumers and producers across the globe. ${ }^{117}$

What is most relevant to this discussion though, is the potential impact on innovation and technology these mergers may have. The companies argue that in order to remain competitive and to have the financial resources necessary for the high cost of research and development, joining forces is necessary. ${ }^{118}$ However, competition can spur innovation. Fewer players in this area means less pressure to develop a new product to compete with that of another supplier. ${ }^{119}$ Less competition may also mean less pressure to release products into the marketplace, slowing the speed of innovation. ${ }^{120}$ How the industry will work with institutions conducting public research is another area of concern, as research in the public sector may be a key factor in making technology accessible in the developing world. ${ }^{121}$ Earlier research

114. Amy Mayer \& Luke Runyon, Why You Should Care About Big Ag Companies Getting Bigger, IowA PuB. Radio (Oct. 27, 2016), http://iowapublicradio.org/post/ why-you-should-care-about-big-ag-companies-getting-bigger\#stream/0 [https://perma .cc/4DKL-D468].

115. Id.

116. Id.; Amy Mayer \& Luke Runyon, Eat or Be Eaten: How Big Ag Came to Be, Iowa Pub. RAdio (Oct. 26, 2016), http://iowapublicradio.org/post/eat-or-be-eatenhow-big-ag-came-be\#stream/0 [https://perma.cc/QZZ4-CTU3].

117. See Mayer \& Runyon, supra note 114; Matthew Perlman, Dow, DuPont Offer Concessions to EU for Planned Merger, Law360 (Feb. 8, 2017, 3:25 PM) https://www law360.com/articles/889749/dow-dupont-offer-concessions-to-eu-for-planned-merger [https://perma.cc/5EZR-UUHU].

118. Mayer \& Runyon, supra note 114 .

119. Sonja Begemann, As Seed Companies Combine, Farmers Suspect Competition and Innovation Will Suffer, AGWEB (May 27, 2016, 5:00 AM), http://www.agweb.com/ article/as-seed-companies-combine-farmers-suspect-competition-and-innovation-willsuffer-naa-sonja-begemann/ [https://perma.cc/YD7C-KQ2C].

120. $I d$.

121. See Margarita Escaler, Public-private Partnerships in Modern Biotechnology, SCIDEV.NeT (Jan. 10, 2002), http://www.scidev.net/global/policy-brief/public-privatepartnerships-in-modern-biotechnolog.html [https://perma.cc/67FZ-DFU8]; CropLife 
in this area indicated there was the potential for concern related to decreased research and development. ${ }^{122}$ The researchers suggested several policy implications, including the need to ensure competition within this market, use of public research to spur private research and increased government investment in research, and the importance of the use of patents to protect intellectual property and encourage research. ${ }^{123}$

Indications are that with divestitures and accommodations offered on the part of the companies, these mergers will be approved and move forward. ${ }^{124}$ With the potential for decreased, or slower, technology development and release due to lack of competition, public research becomes even more important. As noted in the 2002 study on consolidation within the agricultural supplier sector, private companies are not the only source for technology and innovation. ${ }^{125}$ Public research is an underfunded and necessary source of development of new and innovative technologies, not just in the agricultural sector but in information management, conservation, sustainability, and many other related areas that will help us feed the world. ${ }^{126}$ Work being done in the public sector can help spur the development of new technologies focused on addressing environmental concerns and sustainable agricultural practices, as well as providing educational support and

Int'l, Comment to Besides Monsanto, Syngenta Etc. Who Else Do the Research Work in the Development of GM Crops World Wide?, GMO ANswers (Feb. 3, 2014, 8:31 PM), https://gmoanswers.com/ask/besides-monsantosyngenta-etc-who-else-do-re search-work-development-gm-crops-world-wide-how-far [https://perma.cc/L5NRGQGC].

122. David E. Schimmelpfennig et al., The Impact of Seed Industry Concentration on Innovation: A Study of US Biotech Market Leaders, 30 Agric. Econ. 157, 158 (2004). See generally Robert A. Hopkins, Industry Consolidation: Impact on Start-Ups and Innovation, ENDOVAscular TODAY (Feb. 2015), http://evtoday.com/pdfs/ et0215_F4_Hopkins.pdf [https://perma.cc/WBK5-AL8S] (discussing potential negative effects on innovation related to consolidation in medical supply industry).

123. Schimmelpfenniga et al., supra note 122.

124. See, e.g., Ed Carson, DuPont, Dow Chemical Soar on Expected EU Merger OK, Investor's Bus. Daily News (Feb. 22, 2017), http://www.investors.com/news/ dupont-dow-chemical-soar-on-expected-eu-merger-ok-pushing-dow-industrials-to-record-high/ [https://perma.cc/XG9N-X74N]; Aaron Kirchfeld et al., ChemChina Files for U.S. Antitrust Approval on Syngenta Deal, Bloomberg Markets (Jan. 19, 2017, 7:56 PM), https://www.bloomberg.com/news/articles/2017-01-20/chemchina-files-for-us-antitrust-approval-of-syngenta-deal [https://perma.cc/738Q-A82G].

125. Schimmelpfenniga et al., supra note 122.

126. See Nat'l Research Council of the Nat'l Academies, Conclusions and Recommendations, in Spurring Innovation in Food and Agriculture: A ReView of the USDA Agriculture and Food Research Initiative Program 143, 144 (2014); Mark Muller \& Michael Pursell, Making Public Agricultural Research Work for the Public: Research and the Farm Bill, Inst. For Agric. \& Trade Pol'y (May 21, 2012), http://www.iatp.org/documents/making-public-agricultural-researchwork-for-the-public-research-and-the-farm-bill [https://perma.cc/5C95-FWWM]; The Need and Benefit for Food and Agricultural Research, NAT'L COAL. FOR FoOD \& Agric. Research, http://www.ncfar.org/need.asp [https://perma.cc/9G77-KZPY]. 
resources and expertise to others working in these areas. ${ }^{127}$ Funding more research in the public sector may also be a way to help ensure access to the resulting technology for those unable to purchase it on the open market. ${ }^{128}$ Increasing the funds available for scientific and social research in the public sector should be a priority across the globe.

\section{Conservation}

There is only so much that plant technology can do to increase yields if farmers do not also have good soil and adequate natural resources. So much of the public discussion related to agricultural technology centers on plant technology, such as genetic engineering or CRISPR. Technology though can have a major influence on production through developments that improve soil quality ${ }^{129}$ and help address major environmental concerns such as water quality. ${ }^{130}$ Technology will also be a resource in finding ways to both help mitigate agriculture's effect on climate change and address production challenges arising from changes to Earth's climate ${ }^{131}$ as well as concerns over access to water and water usage in order to reduce agricul-

127. See About, Samuel Roberts Noble Found., https://www.noble.org/about/ [https://perma.cc/QY9F-BNVF]; About, KIRCHNER IMPACT Found., http://kirchnerimpact.com/about/ [https://perma.cc/FPU2-AFX6] (stating the activities of the foundation "aim to generate a measurable, social and/or environmental benefit, primarily across four sectors: Agriculture/Food, Health/Life Science, Energy/Resources and Education").

128. Agricultural Development: Strategy Overview, Bill \& Melinda Gates Found., http://www.gatesfoundation.org/What-We-Do/Global-Development/Agricultural-Development [https://perma.cc/KBD4-CWG7].

129. Soil Quality, Penn St. Extension, http://extension.psu.edu/business/startfarming/soils-and-soil-management/soil-quality [https://perma.cc/7KKX-TXC7] (discussing aspects of soil quality, including many areas that scientific research and technology can help farmers better understand options and ways to improve and maintain soil quality); Sanjai J. Parikh \& Bruce R. James, Soil: The Foundation of Agriculture, 3 NAture Educ. KnOwLedge 2 (2012), http://www.nature.com/scitable/knowledge/li brary/soil-the-foundation-of-agriculture-84224268 [https://perma.cc/7NV5-D6Q9].

130. Cy Jones, Tools to Improve Water Quality, World Res. Inst.: Blog (Aug. 29, 2012), http://www.wri.org/blog/2012/08/tools-improve-water-quality [https://perma.cc/ GE87-VCZM].

131. See generally Dhanush Dinesh \& Sonja Vermeulen, Climate Change Adaptation in Agriculture: Practices and Technologies, CGIAR (Nov. 2016) https://cgspace .cgiar.org/bitstream/handle/10568/71051/SBSTA44-Agricultural-practices-technolo gies.pdf [https://perma.cc/SR5P-BGYS]; Climate Change and Agriculture, U.C. Agric. Issues CTR. (July 2009), https://www.cdfa.ca.gov/agvision/docs/Climate Change_and_Agriculture.pdf [https://perma.cc/A2UJ-7EX6]; Travis Lybbert \& Daniel Sumner, Agricultural Technologies for Climate Change Mitigation and Adaptation in Developing Countries: Policy Options for Innovation and Technology Diffusion, INT'L CTr. FOR Trade \& Sustainable Dev. (May 2010), http://www.ictsd.org/downloads/ 2010/06/agricultural-technologies-for-climate-change-mitigation-and-adaptation-indeveloping-countries_web.pdf [https://perma.cc/387V-SUM9]. 
ture's depletion of this resource and to still thrive when water is scarce. ${ }^{132}$

The role of technology surrounding "big data" may also play a key role in conservation efforts in agricultural production and help form multi-level partnerships within the industry. For example, the Drake Agricultural Law Center is currently working on research that in part, looks at the use of big data to assist with soil conservation efforts. ${ }^{133}$ As major food companies seek to better quantify the sustainability of their food chain and agricultural inputs, ${ }^{134}$ big data becomes an important tool in helping track the value of sustainability efforts at the farm level, while also serving as a way to make more sustainable and efficient production decisions. ${ }^{135}$ Technologies involving precision agriculture and data management can help companies and their suppliers both meet goals involving environmental improvements and efficiencies. The question of data ownership is one that looms over these discussions though, and can have major impacts on producers financially and potentially in maintaining control over production decisions and remaining competitive. ${ }^{136}$

Investment in research into agroecology and precision agriculture can help develop methods of production that are more efficient in use of resources and in costs of production, as well as more sustainable. ${ }^{137}$ As we consider the roles of agriculture and technology in feeding the

132. Erica Gies, New Technology Reduces Agricultural Water Consumption, Forbes (Oct. 25, 2011, 11:34 AM), https://www.forbes.com/sites/ericagies/2011/10/25/ new-technology-reduces-agricultural-water-consumption/\#6312f8d665c8 [https://per ma.cc/YM28-BPS8]; Katherine Noyes, Can Technology Help Us Survive California's Drought?, ForTune (Aug. 11, 2014), http://fortune.com/2014/08/11/can-technologyhelp-us-survive-californias-drought/ [https://perma.cc/D7XR-XFR7]; Darren Quick, New Water Retention Technology Quenches Crop Thirst in Drought Conditions, New AtLAs (Jan. 31, 2013), http://newatlas.com/msu-subsurface-water-retention-technol ogy/26066/ [https://perma.cc/S2YC-CXFV].

133. Draft of web site on file with Author.

134. Our Approach to Reporting, UNILEVER, https://www.unilever.com/sustainableliving/the-sustainable-living-plan/our-approach-to-reporting/ [https://perma.cc/U79H52TV]; Nicole Erwin, Data Farming: How Big Data Is Revolutionizing Big Ag, ReSOURCE (Sept. 16, 2016), http://ohiovalleyresource.org/2016/09/16/data-farming-bigdata-revolutionizing-big-ag/ [https://perma.cc/6NVC-244N].

135. John Roach, Can Data-Driven Agriculture Help Feed a Hungry World?, YALE ENV'T 360 (Mar. 3, 2016), http://e360.yale.edu/features/can_data-driven_agriculture_ help_feed_a_hungry_world [https://perma.cc/H94P-L23G].

136. See Erwin, supra note 134; Sid Gorham, Your Farm Is Worth More than Its Parts, if You Protect Your Intellectual Property, Corn \& Soybean Dig. (July 21, 2016), http://www.cornandsoybeandigest.com/precision-ag/your-farm-worth-more-itsparts-if-you-protect-your-intellectual-property [https://perma.cc/F96L-WU44].

137. Union of Concerned Scientists, Counting on Agroecology: Why We Should Invest More in the Transition to Sustainable Agriculture 2-4 (2015), available at http://www.ucsusa.org/sites/default/files/attach/2015/11/ucs-counting-on-agroecology-2015.pdf [https://perma.cc/5K47-M4RV]; Linda Ulrich, Precision Ag Makes Farming More Sustainable, Profitable, IANR News, http://ianrnews.unl .edu/precision-ag-makes-farming-more-sustainable-profitable [https://perma.cc/ 3YQZ-L5PP]. 
world, conservation of resources needs to be a major focus of programs and development because without adequate resources, feeding the world will be an unachievable goal.

\section{Thinking Outside the Box, Creativity is Key TO FEEDING THE WORLD}

Creativity is at the heart of technology and innovation. As we work to develop ways to feed an expanding population, increase production in developing countries, maintain and improve quality of natural resources, and continue high levels of production in the U.S. despite loss of arable land, it is going to take some creative thinking to develop new products and techniques to meet these goals.

Creative uses of existing intellectual property protections can help protect growers and create markets for new or emerging agricultural products. One example is the argument for marijuana appellations in California and Canada, similar to the regions for wine and other food products that already exist. ${ }^{138}$ Technology can also help develop and expand new protein sources of food, including sources that are plant based, more sustainable, and have less impact on the environment than animal production.

For example, insects as food is not a new idea, even if not overly popular in the U.S, and increased consumption of insects may help both provide needed nutrition, but with decreased environmental and production costs than other forms of protein (i.e. meat). ${ }^{139}$ Recently, a new production operation in Western North Carolina was described as a "startup [that] blends agriculture and technology to build high-production cricket habitats and create a new food source for people and livestock." ${ }^{140}$ Relying heavily on technology to drive an efficient, datadriven operation, the production facility is viewed as environmentallyfriendly, and as a sustainable way to provide high quality protein within a short period of time. ${ }^{141}$

Plant-based meat substitutes are also not a new product, and are a way to provide consumers protein sources with less environmental im-

138. Ryan Boudin Stoa, Marijuana Appellations: The Case for Cannabicultural Designations of Origin, 11 HARV. L. \& POL'y REv. (forthcoming 2017) (available at https://papers.ssrn.com/sol3/papers2.cfm?abstract_id=2815070); Devon Scoble, Going Gourmet: What Would Cannabis Appellations Look like in Canada?, LIFT NEws (Dec. 6, 2016), https://news.lift.co/going-gourmet-what-would-cannabis-appellations-looklike-in-canada/ [https://perma.cc/398L-5PMP].

139. Jennifer S. Holland, U.N. Urges Eating Insects; 8 Popular Bugs to Try, NAT'L GeOGRAPHIC (May 14, 2013), http://news.nationalgeographic.com/news/2013/13/1305 14-edible-insects-entomophagy-science-food-bugs-beetles/ [https://perma.cc/7QAC-Y P27].

140. Mackensy Lunsford, Bitten by the Bug: New Tech-Driven Cricket Farm for WNC, CITIZEN-TIMES (Sept. 29, 2016, 2:14 PM) http://www.citizen-times.com/ story/news/local/2016/09/29/bitten-bug-new-tech-driven-cricket-farm-wnc/91218304/ [https://perma.cc/HF8B-GKYY].

141. Id. 
pact than animal production. ${ }^{142}$ Technology is helping to not only make production of the necessary plants more efficient and sustainable, but also to make the end product more appealing to consumers for taste and appearance. ${ }^{143}$

While plant-based proteins may have less of an environmental impact than livestock production, there is still an impact. To reduce the environmental impact of proteins even further, research is being done now on the idea of "clean meat," meaning "meat grown through cellular agriculture" in a setting commonly referred to as a "meat brewery." 144 Instead of trying to develop meat "alternatives," cellular agriculture produces meat products, but without the animals. ${ }^{145}$ This is novel technology. . .imagine growing ground beef in a Petri dish. Proponents believe this can be a more efficient source of meat production that avoids not only the environmental impacts of livestock production, but some of the food safety concerns that arise from animal production as well. ${ }^{146}$

Creative thinking and technology can come up with unique and novel ways to tackle environmental and production concerns in agriculture. From the idea of forest towers in cities to reduce the effects of air pollution, technology can also work to develop agricultural production towers or other novel uses of space in urban areas to increase production in areas where there open land is a premium. ${ }^{147}$ Focusing on problems affecting small farmers can also help develop novel solutions to problems that are addressed much differently in operations with larger scales of production. ${ }^{148}$

Use of data technology in numerous new ways also has the potential for not just encouraging new ways of production, but also in providing insight as to how to make current operations more efficient and effec-

142. Bruce Friedrich, Nerds over Cattle: How Food Technology Will Save the World, WIRED (Oct. 7, 2016, 10:00 AM), https://www.wired.com/2016/10/nerds-cattle -food-technology-will-save-world/ [https://perma.cc/MYG3-JQ74].

143. Id

144. Id.; see The Future of Meat, ClEANMEAT.COM, http://cleanmeat.com/ [https:// perma.cc/S3DW-6CFZ].

145. See The Future of Meat, supra note 144.

146. See id.

147. See Maria Gallucci, China's Big, Beautiful, Green 'Vertical Forests' Will Suck up Toxic Smog, Mashable (Feb. 7, 2017), http://mashable.com/2017/02/07/china-verti cal-forest-smog/\#aw8kRVpybkqA [https://perma.cc/FNQ4-PYZ3]; Foody Garden Towers and the Future of Urban Gardening, FuturE ThINGs, http://thefutureofthings .com/8898-foody-garden-towers-and-the-future-of-urban-gardening/ [https://perma.cc/ R9WE-79CK] (discussing a personal version of a garden tower); Jeff Wells, Indoor Farming: Future Takes Root in Abandoned Buildings, Warehouses, Empty Lots \& High Rises, InT'L Bus. Times (Aug. 9, 2014, 9:38 AM), http://www.ibtimes.com/indoor-farming-future-takes-root-abandoned-buildings-warehouses-empty-lots-highrises-1653412 [https://perma.cc/ZX4N-RZ2F].

148. See Asia Embraces Creative Technology to Enhance Agriculture, Asia Today (Jan. 25, 2017), http://asiatoday.com/pressrelease/asia-embraces-creative-technologyenhance-agriculture [https://perma.cc/C2D4-VHKZ]. 
tive. ${ }^{149}$ Data technology can recognize patterns, identify constants across massive pools of data, and allow for detailed farm-level information to be provided quickly and in a way that is understandable. ${ }^{150}$

We have touched on numerous issues in this discussion and areas where technological advances are having a major impact on agricultural production and work to support developing nations. By its very nature, technology and science is creative and innovative. While industry may be willing to start to think outside the box in terms of developing new protein sources or methods of production, that is only sustainable when there is a market for the product. All of this again ties in to the importance of collaboratively working to develop products and technologies, while also working to effectively communicate the science, the technology, the benefits and challenges to the world.

\section{Conclusion}

Today's discussion touches only briefly on a handful of the many challenges and issues that come into play when discussing how agriculture and technology can work together to feed the world. Underlying many of these areas though, are a few other key areas that are important, such as:

- Work on the 2018 Farm Bill, which began in earnest in February 2017 with the first field hearing. ${ }^{151}$

- U.S. policies towards international relations, cooperation, and participation in international agreements may have an impact on anti-hunger programs and initiatives. A new administration means many changes and often changes in priorities. It is not clear at this time how the Trump administration policies may change related to international aid, including food aid, or in support to educational and developmental programs across the globe that focus on many of the issues discussed above.

149. See Lyndsey Gilpin, How Big Data Is Going to Help Feed Nine Billion People By 2050, TeChRepublic http://www.techrepublic.com/article/how-big-data-is-goingto-help-feed-9-billion-people-by-2050/ [https://perma.cc/7D8V-NAM3]; Michael Kassner, Conservis Brings Big Data and Analytics To Farming with Its Cloud-Based Platform, TechRepublic (Oct. 10, 2014, 6:50 AM), http://www.techrepublic.com/article/ conservis-brings-big-data-and-analytics-to-farming-with-its-cloud-based-platform/ [https://perma.cc/6WZ5-2HXU].

150. See Gilpin, supra note 149; Kassner, supra note 149.

151. See Steve Davies, House Hearing Kicks off 2018 Farm Bill Effort, AgriPulse (Feb. 15, 2017, 6:30 PM), https://www.agri-pulse.com/articles/8921-house-hearingkicks-off-2018-farm-bill-effort [https://perma.cc/S6BT-FLLN]. Farm bill programs have both a direct and indirect impact on technology, through research and funding as well as programs that may encourage the use of certain technologies. There are also numerous programs aimed at increasing environmental practices and use of sustainable agricultural production methods support development of new technologies for producers in these areas. See generally NAT'L Research Council of the NAT'L ACADEMIES, supra note 126. 
- Changes to the Coordinated Framework, the "overarching system of biotech regulation" in the U.S. ${ }^{152}$ The Obama Administration released an update to the framework in mid-January 2017, to mixed reactions from the industry. ${ }^{153}$ It remains to be seen what, or if, the Trump Administration will do with these proposed changes, and it is possible the changes will be rolled back.

- The impact of private litigation on innovation and release of new technology into the marketplace. ${ }^{154}$

All can have a major impact on the agricultural and technology industries, as well as consumer confidence in these industries and the safety of food. Even short term disruptions in support for developing countries or in research programs can have long term impacts due to the loss of momentum or relationships and research capabilities.

Feeding the world is a phrase used often and in a variety of ways. Feeding the world in the 21st Century is not just an agriculture issue. It is not just a technology issue. It is not even just an issue of technology and agriculture combined. In order to successfully feed the world, now and in the future, we need to ensure that we continue to look at issues that affect hunger, agricultural production and innovation from a holistic perspective. Long term success also means that new technologies incorporate a focus on reducing agriculture's environmental impact and improving sustainable practices.

For any chance at success, we need to collaborate on both large and small scales to ensure that growers have access to inputs, security in their land, and adequate storage and transportation. We need to work with governments to develop strong food policies that are forward thinking and support these initiatives. We need to develop educational programs that teach how to produce food in an efficient manner, but also educate growers and consumers about new technology or production methods. The list of needs is long and requires intensive resources beyond just the financial. Feeding the world is only possible if industry, government, producers, consumers, trade associations, NGOs, and

152. Kelly Servick, Proposed U.S. Biotech Rules Raise Industry Hopes and Anxieties, SCI. (Jan. 27, 2017, 1:30 PM), http://www.sciencemag.org/news/2017/01/proposedus-biotech-rules-raise-industry-hopes-and-anxieties [https://perma.cc/XBZ8-ZD86].

153. Id.; see also U.S. Envtl. Prot. Agency, U.S. Food \& Drug Admin., U.S. Dep't of Agric., Modernizing the Regulatory System for Biotechnology Products: Final Version of the 2017 Update to the Coordinated Framework for the Regulation of Biotechnology, U.S. Environmental ProtecTION AGENCY (2017).

154. Sonja Begemann, Farmer Lawsuits over Syngenta Corn Continue to Grow, AGWeb (Nov. 13, 2015, 10:30 AM), http://www.agweb.com/article/farmer-lawsuitsover-syngenta-corn-continue-to-grow-naa-sonja-begemann/ [https://perma.cc/9LPFN373]; see also Thomas P. Redick et al., Litigation and Regulatory Challenges to Innovation in Biotech Crops, 20 Drake J. AgRIC. L. 71, 73-79 (2015) (providing an overview and background of what led to Syngenta litigation). 
a never ending list of other entities work collaboratively, communicate effectively and respectfully, and think creatively about potential solutions and partnerships. 
